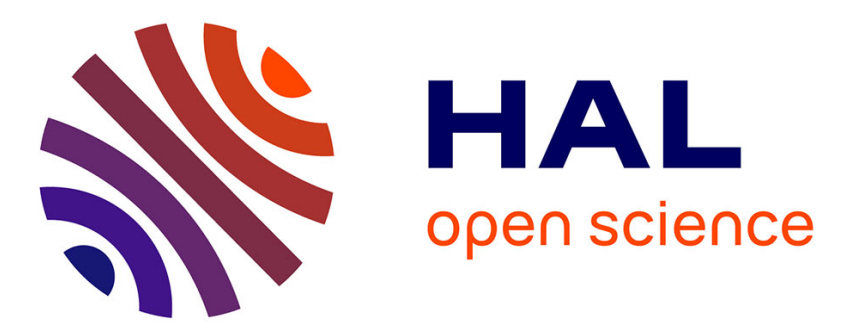

\title{
Electrocatalytic O 2 Activation by Fe Tetrakis(pentafluorophenyl)porphyrin in Acidic Organic Media. Evidence of High-Valent Fe Oxo Species
}

Nikolaos Kostopoulos, Celia Achaibou, Jean-Marc Noel, Fredeŕic Kanoufi, Marc Robert, Claire Fave, Elodie Anxolabéhère-Mallart

\section{To cite this version:}

Nikolaos Kostopoulos, Célia Achaibou, Jean-Marc Noel, Fredeŕic Kanoufi, Marc Robert, et al.. Electrocatalytic $\mathrm{O} 2$ Activation by Fe Tetrakis(pentafluorophenyl)porphyrin in Acidic Organic Media. Evidence of High-Valent Fe Oxo Species. Inorganic Chemistry, 2020, 59 (16), pp.11577-11583. 10.1021/acs.inorgchem.0c01379 . hal-02951618

HAL Id: hal-02951618

https://hal-univ-paris.archives-ouvertes.fr/hal-02951618

Submitted on 28 Sep 2020

HAL is a multi-disciplinary open access archive for the deposit and dissemination of scientific research documents, whether they are published or not. The documents may come from teaching and research institutions in France or abroad, or from public or private research centers.
L'archive ouverte pluridisciplinaire HAL, est destinée au dépôt et à la diffusion de documents scientifiques de niveau recherche, publiés ou non, émanant des établissements d'enseignement et de recherche français ou étrangers, des laboratoires publics ou privés. 


\title{
Electrocatalytic $\mathrm{O}_{2}$ Activation by Fe \\ Tetrakis(pentafluorophenyl)porphyrin in Acidic Organic Media. Evidence of High-Valent Fe Oxo Species
}

\author{
Nikolaos Kostopoulos, Célia Achaibou, Jean-Marc Noël, Frédéric Kanoufi, Marc Robert, Claire Fave, \\ and Elodie Anxolabéhère-Mallart*
}
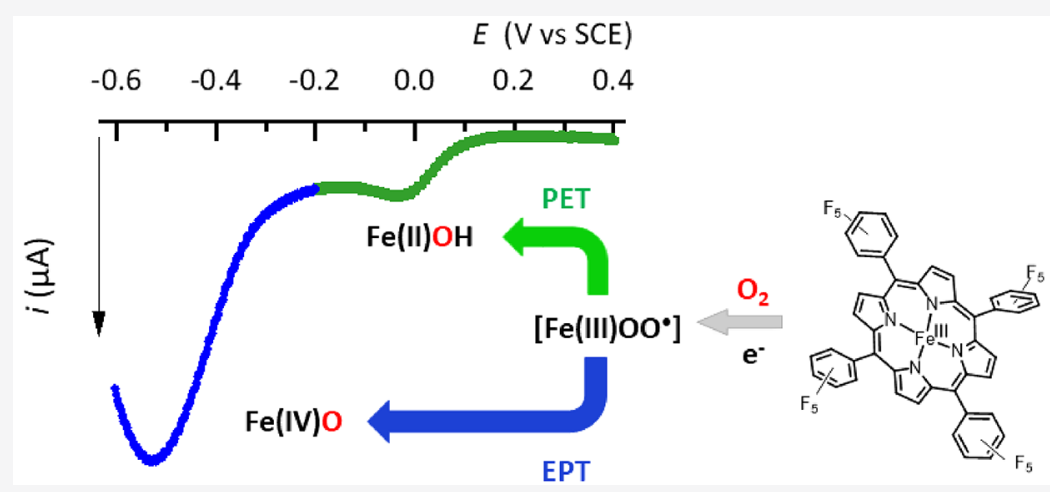

ABSTRACT: $\mathrm{O}_{2}$ activation under mild conditions remains a weighty challenge for chemists. Herein we report a study of electrochemical $\mathrm{O}_{2}$ reductive activation catalyzed by $\mathrm{Fe}{ }^{\mathrm{III}}\left(\mathrm{F}_{20} \mathrm{TPP}\right) \mathrm{Cl}$, by means of cyclic voltammetry and $\mathrm{UV}-\mathrm{vis}$ spectroelectrochemistry in acidic solutions of $N, N$-dimethylformamide. Two parallel catalytic pathways have been evidenced occurring at different overpotentials. At high overpotential a classical electron-proton (EPT) pathway where protonation of Fe peroxo ultimately leads to the formation of high-valent Fe oxo species dominates. At low overpotential a proton-electron (PET) pathway involving a hydrosuperoxo species has been identified.

\section{INTRODUCTION}

Oxidation reactions are of fundamental importance not only in Nature but also in the chemical industry for the production of quantities of organic molecules. In order to successfully perform such processes, stoichiometric harmful oxidants, noble-metal catalysts, and/or high temperatures and pressures are generally required and large quantities of waste are generated. ${ }^{1}$ The current economic, environmental, and climatic context demonstrates the need to urgently develop greener processes. In this framework, the ideal "green" oxidant is molecular oxygen $\left(\mathrm{O}_{2}\right)$ because it is abundant and environmentally benign (with $\mathrm{H}_{2} \mathrm{O}$ as a byproduct). ${ }^{2}$ However, the kinetic inertia of $\mathrm{O}_{2}$ (triplet ground state) necessitates reductive activation steps. Highly efficient and selective oxidation reactions are achieved in Nature by metalloenzymes such as heme-containing CytP450, which unravel the $\mathrm{O}_{2}$ potent oxidizing power under mild conditions through the so-called reductive activation. ${ }^{3-6}$ This corresponds to partial $\left(2 \mathrm{e}^{-}\right)$and controlled reduction of $\mathrm{O}_{2}$ bound at the $\mathrm{Fe}$ active site via sequential $\mathrm{e}^{-}$and $\mathrm{H}^{+}$transfers to realize $\mathrm{O}-\mathrm{O}$ bond cleavage. The $4 \mathrm{e}^{-}$and $4 \mathrm{H}^{+}$reduction of $\mathrm{O}_{2}$ to $\mathrm{H}_{2} \mathrm{O}$ (ORR), a key reaction in fuel cell technology, also occurs through activation of $\mathrm{O}_{2}$ and breaking of $\mathrm{O}-\mathrm{O}$ bonds at hemecontaining active site of cytochrome $c$ oxidase. ${ }^{7,8}$

Taking inspiration from the structure and efficient reactivity of these natural systems, researchers have carried out many chemical synthetic efforts over the past decades. ${ }^{6,9-11}$ In order to achieve better control over proton and electron delivery, mechanistic studies and identification of reactive intermediates are necessary. Recently, the Mayer group obtained important insights into the kinetics of the ORR catalyzed by $\mathrm{Fe}$ porphyrins. $^{12,13}$ In a parallel effort, our own approach relies on controlling the production of some key postulated intermediate species such as $\mathrm{Fe}^{\mathrm{III}} \mathrm{OO}^{-}$(peroxo), $\mathrm{Fe}^{\mathrm{III}} \mathrm{OOH}$ (hydroperoxo), and $\mathrm{Fe}^{\mathrm{IV}} \mathrm{O}$ (oxo) (Scheme 1) and thus improving the understanding of the whole spectrum of 
Scheme 1. Proposed Catalytic Cycle of $\mathrm{O}_{2}$ Reductive Activation by $\mathrm{Fe}^{\mathrm{III}}\left(\mathrm{F}_{20} \mathrm{TPP}\right) \mathrm{Cl}^{a}$

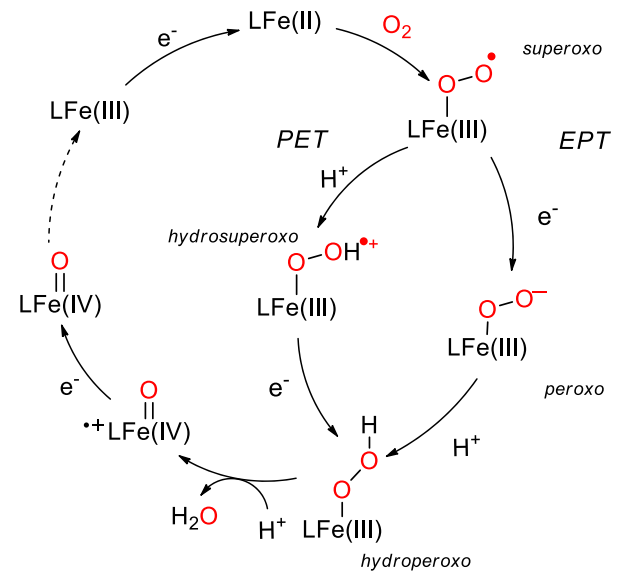

${ }^{a}$ Total charges of intermediates and axial ligands are omitted for clarity.
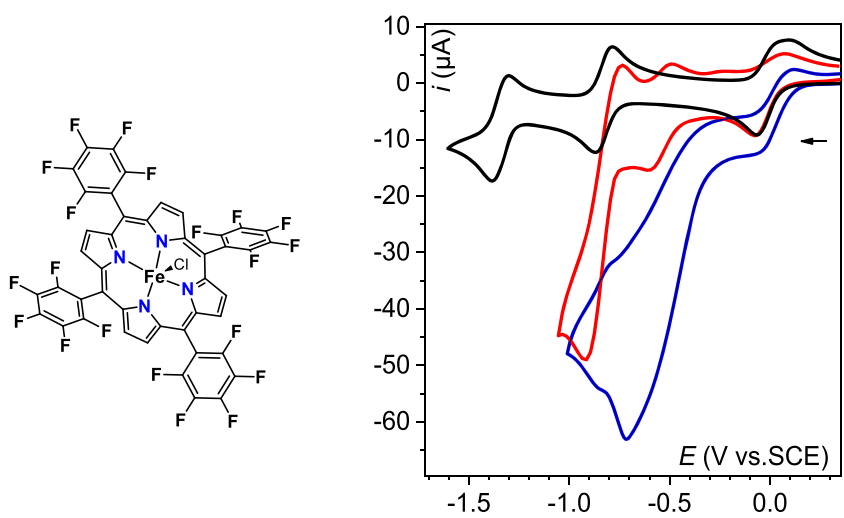

Figure 1. (left) Molecular structure of $\mathrm{Fe}^{\mathrm{III}}\left(\mathrm{F}_{20} \mathrm{TPP}\right) \mathrm{Cl}$. (right) CVs at a glassy-carbon-disk electrode of a $1 \mathrm{mM}$ solution of $\mathbf{1}$ in DMF + TBAPF $_{6}(0.1 \mathrm{M})$, with $v=0.1 \mathrm{~V} \mathrm{~s}^{-1}$ and $T=293 \mathrm{~K}$ : under argon (black trace); under $\mathrm{O}_{2}$ (air saturated, $1 \mathrm{mM}$ ) (red trace); under $\mathrm{O}_{2}$ with $10 \mathrm{mM} \mathrm{HClO}_{4}$ (blue trace).

reductive activation of $\mathrm{O}_{2}$ by $\mathrm{Fe}$ porphyrins, not only the ORR reaction. $^{6-11,14}$

In this context, we recently reported the electrochemical generation of $\mathrm{Fe}^{\mathrm{III}} \mathrm{OO}^{-}$peroxo and $\mathrm{Fe}^{\mathrm{III}} \mathrm{OOH}$ hydroperoxo species from organic solutions of the commercially available $\left[\mathrm{Fe}^{\mathrm{III}}\left(\mathrm{F}_{20} \mathrm{TPP}\right) \mathrm{Cl}\right] \quad\left(1 ; \mathrm{F}_{20} \mathrm{TPP}=5,10,15,20\right.$-tetrakis- (pentafluorophenyl)porphyrinate) and $\mathrm{O}_{2}$ in an organic medium. $^{15}$ Using complementary techniques, i.e. cyclic voltammetry and low-temperature electronic absorption and EPR spectroscopy, we demonstrated that reductive activation of $\mathrm{O}_{2}$ could be achieved using $\mathrm{Fe}^{\mathrm{III}}\left(\mathrm{F}_{20} \mathrm{TPP}\right) \mathrm{Cl}$ through electrochemical reduction of the $\mathrm{Fe}^{\mathrm{III}} \mathrm{OO}^{\bullet}$ superoxo complex (at an electrolysis potential of $-0.60 \mathrm{~V}$ vs SCE), leading to the formation of the $\mathrm{Fe}^{\mathrm{III}} \mathrm{OO}^{-}$peroxo complex (Scheme 1 ). In this paper, we report the effect of protons and of potential values on the generation and reactivity of such intermediates. This approach allowed us to identify and probe, in addition to the classical electron-proton transfer (EPT), a new and less demanding (occurring at more positive potential) protonelectron transfer (PET) pathway.

\section{CYCLIC VOLTAMMETRY UNDER VARIOUS ACIDIC CONDITIONS}

Figure 1 shows cyclic voltammograms (CVs) obtained for the iron porphyrin 1 under argon and $\mathrm{O}_{2}$ and in the presence of acid. Under an argon atmosphere, CVs display three reversible monoelectronic waves corresponding to the successive $\mathrm{Fe}^{\mathrm{III}}$ / $\mathrm{Fe}^{\mathrm{II}}\left(E_{1 / 2}=+0.02 \mathrm{~V}\right.$ vs SCE$), \mathrm{Fe}^{\mathrm{II}} / \mathrm{Fe}^{\mathrm{I}}\left(E_{1 / 2}=-0.80 \mathrm{~V}\right.$ vs $\mathrm{SCE})$, and $\mathrm{Fe}^{\mathrm{I}} / \mathrm{Fe}^{0}\left(E_{1 / 2}=-1.31 \mathrm{~V}\right.$ vs SCE) reduction processes (Figure 1, black trace). ${ }^{16}$ Upon $\mathrm{O}_{2}$ saturation, a new monoelectronic wave appears at ca. $E_{\mathrm{pc}}=-0.60 \mathrm{~V}$ vs SCE (Figure 1, red trace) attributed to the reduction of $\mathrm{Fe}^{\mathrm{III}} \mathrm{O}_{2}{ }^{\bullet}$ into the $\mathrm{Fe}^{\mathrm{III}} \mathrm{OO}^{-}$complex (Scheme 1). ${ }^{15}$ The large peak at $-0.85 \mathrm{~V}$ vs SCE in the red trace corresponds to the direct reduction of the excess $\mathrm{O}_{2}$ in the diffusion layer that is not bound to the $\mathrm{Fe}$. When a strong acid $\left(\mathrm{HClO}_{4}\right)$ is added, the signal at $-0.60 \mathrm{~V}$ sharply increases, indicative of a catalytic process $^{17}$ (Figure 1, blue trace) attributed to the $\mathrm{O}_{2}$ catalytic reduction ${ }^{18}$ triggered by the protonation of the $\mathrm{Fe}^{\mathrm{III}} \mathrm{OO}^{-}$ intermediate (Scheme 1). To describe this catalytic process, the direct reduction of $\mathrm{O}_{2}$ on a glassy-carbon electrode in the presence of protons has to be subtracted. For this purpose, CVs of air-saturated DMF solutions in the absence of porphyrin with various concentrations of $\mathrm{HClO}_{4}$ were recorded (Figure $\mathrm{S} 1$, left) and then subtracted from the traces shown in Figure 1. Figure 2A displays the current responses thus obtained at each concentration of $\mathrm{HClO}_{4}$. Figure $2 \mathrm{~B}, \mathrm{C}$ shows the dependence of the peak potential of the $\mathrm{Fe}^{\mathrm{III}} \mathrm{OO} \%$ $\mathrm{Fe}^{\mathrm{III}} \mathrm{OO}^{-}$couple $\left(E_{\mathrm{p}, \mathrm{Fe}} \mathrm{III}^{\mathrm{II}} \mathrm{OO}^{\bullet} / \mathrm{Fe}^{\mathrm{III}} \mathrm{OO}^{-}\right)$and of the normalized peak current $\left(i_{\mathrm{p}} / i^{0}\right)$ with the concentration of acid. With less than 2 equiv of $\mathrm{HClO}_{4}$ the peak potential of the $\mathrm{Fe}^{\mathrm{III}} \mathrm{OO}^{\bullet} / \mathrm{Fe}^{\mathrm{III}} \mathrm{OO}^{-}$ couple $\left(E_{\mathrm{p}, \mathrm{Fe}}^{\text {III }} \mathrm{OO}^{\circ} / \mathrm{Fe}^{\mathrm{III}} \mathrm{OO}^{-}\right)$, initially centered at $-0.60 \mathrm{~V}$, slightly
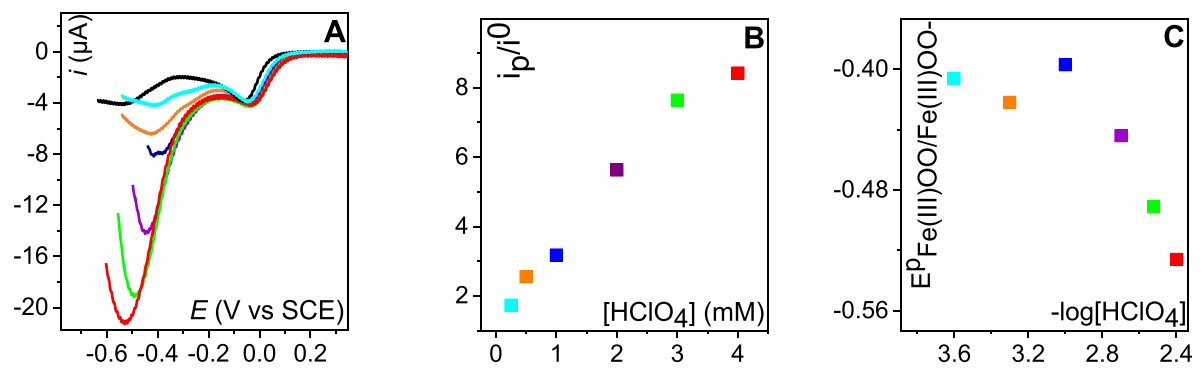

Figure 2. (A) CVs of $1(0.5 \mathrm{mM})$ in $\mathrm{DMF}+\mathrm{TBAPF}_{6}(0.1 \mathrm{M})$ with $v=0.1 \mathrm{~V} \mathrm{~s}^{-1}$ and $T=293 \mathrm{~K}$ at a glassy-carbon electrode, under $\mathrm{O}_{2}($ air saturated, $1 \mathrm{mM}$ ) (black line) and in the presence of increasing concentrations of $\mathrm{HClO}_{4}(0.025 \mathrm{mM} /$ light blue, $0.5 \mathrm{mM} /$ orange, $1 \mathrm{mM} / \mathrm{blue}, 2$ $\mathrm{mM}$ /violet, $3 \mathrm{mM} /$ green, and $4 \mathrm{mM} / \mathrm{red}$ ), after subtraction of the current recorded in the absence of porphyrin (see Figure S1). For clarity only the forward scan is shown. Variation of $(\mathrm{B}) i_{\mathrm{p}} / i^{0}$ and $(\mathrm{C})$ the peak potential for the $\mathrm{Fe}^{\mathrm{III}} \mathrm{OO}^{\bullet} / \mathrm{Fe}^{\mathrm{III}} \mathrm{OO}^{-}$redox couple with increasing concentrations of acid. The color codes are identical in $(\mathrm{A})-(\mathrm{C})$. 
shifts to a less negative potential, indicative of an electron transfer followed by a fast proton transfer (EC) process. Upon an increase in the acid concentration, the peak potential shifts toward more negative values and the increase of $i_{\mathrm{p}} / i^{0}$ indicates a catalytic process. These experimental observations suggest that, in a CytP450-like behavior, ${ }^{3}$ the protonation of the $\mathrm{Fe}^{\mathrm{III}} \mathrm{OO}^{-}$peroxo intermediate involves more than one proton before the $\mathrm{O}-\mathrm{O}$ bond breaking occurs and the catalytic process starts. Full kinetic analysis of this catalytic process is beyond the scope of the present study.

In addition to this strong catalytic current, a slight increase in the current at the level of the $\mathrm{Fe}^{\mathrm{III}} / \mathrm{Fe}^{\mathrm{II}}$ wave is also observed at $+0.02 \mathrm{~V}$ vs SCE along with a modest anodic shift. Figure 3
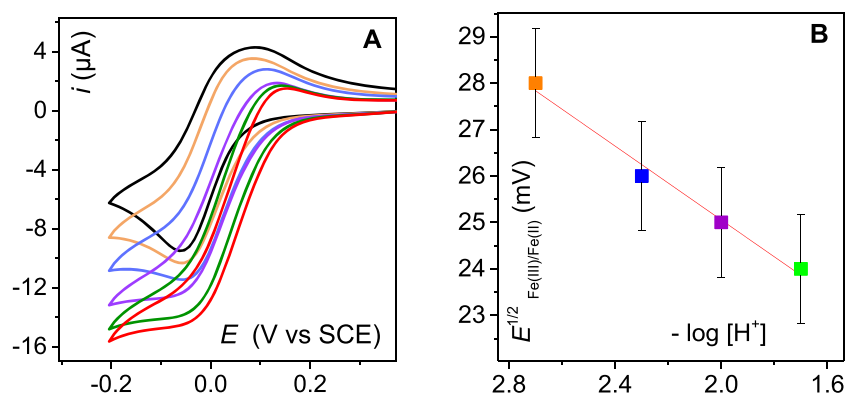

Figure 3. (A) CVs sof $1(0.5 \mathrm{mM})$ in $\mathrm{DMF}+\mathrm{TBAPF}_{6}(0.1 \mathrm{M})$ with $v$ $=0.1 \mathrm{~V} \mathrm{~s}^{-1}$ and $T=293 \mathrm{~K}$, at a glassy-carbon electrode under $\mathrm{O}_{2}$ (air saturated) in the presence of increasing concentrations of $\mathrm{HClO}_{4}(1$ $\mathrm{mM}$ /orange, $2 \mathrm{mM} /$ blue, $5 \mathrm{mM} /$ violet, $10 \mathrm{mM}$ /green, and $20 \mathrm{mM}$ / red). (B) Variation of the half-wave potential of the $\mathrm{Fe}^{\mathrm{III}} / \mathrm{Fe}^{\mathrm{II}}$ couple with increasing concentrations of acid. The color codes are identical in (A) and (B).

shows the half-wave potential evolution of this redox couple upon addition of increasing amounts of $\mathrm{HClO}_{4}$ (up to 20 $\mathrm{mM}$ ). In the absence of acid under argon (black trace) the $\mathrm{CV}$ exhibits a classical cathodic wave corresponding to the reduction of $\mathrm{Fe}^{\mathrm{III}}\left(\mathrm{F}_{20} \mathrm{TPP}\right) \mathrm{Cl}$, with the anodic wave being a composite involving two overlapping waves (see the Supporting Information for details). Upon addition of $\mathrm{HClO}_{4}$ in the presence of oxygen, an increase in the cathodic current occurs with a concomitant decrease in the anodic component until the wave becomes fully irreversible and plateaus, indicative of a kinetically controlled catalytic process (Figure 3).

Meanwhile, the addition of $\mathrm{HClO}_{4}$ to a porphyrin solution in the absence of $\mathrm{O}_{2}$ does not lead to any current variation (Figure S5). These observations indicate that a catalytic process involving both $\mathrm{O}_{2}$ and protons is triggered at the $\mathrm{Fe}^{\mathrm{III}}$ / $\mathrm{Fe}^{\mathrm{II}}$ reduction wave. In this process, the $\mathrm{Fe}$ superoxo complex $\mathrm{Fe}^{\mathrm{III}} \mathrm{O}_{2}{ }^{\bullet}$ generated at the first reduction wave is further protonated in the presence of the strong acid $\left(\mathrm{HClO}_{4}\right)$ to give the hydrosuperoxo $\mathrm{Fe}^{\mathrm{III}} \mathrm{O}_{2}{ }^{\bullet} \mathrm{H}^{+}$species and then the reduced $\mathrm{Fe}^{\mathrm{III}} \mathrm{OOH}$ hydroperoxo intermediate upon one-electron transfer (Figure 4, PET green path). This PET pathway results in the overall $\mathrm{O}-\mathrm{O}$ bond breaking at a remarkably weakly negative potential of only $+0.02 \mathrm{~V}$ vs SCE. At this potential, the EPT pathway (Figure 4, blue path) is not thermodynamically accessible, since the $\mathrm{Fe}^{\mathrm{III}} \mathrm{OO}^{-}$peroxo species could not be formed. ${ }^{15}$ The PET pathway lead to a smaller catalytic current yet occurs at a much lower cathodic potential in comparison to EPT, being energetically more favorable.

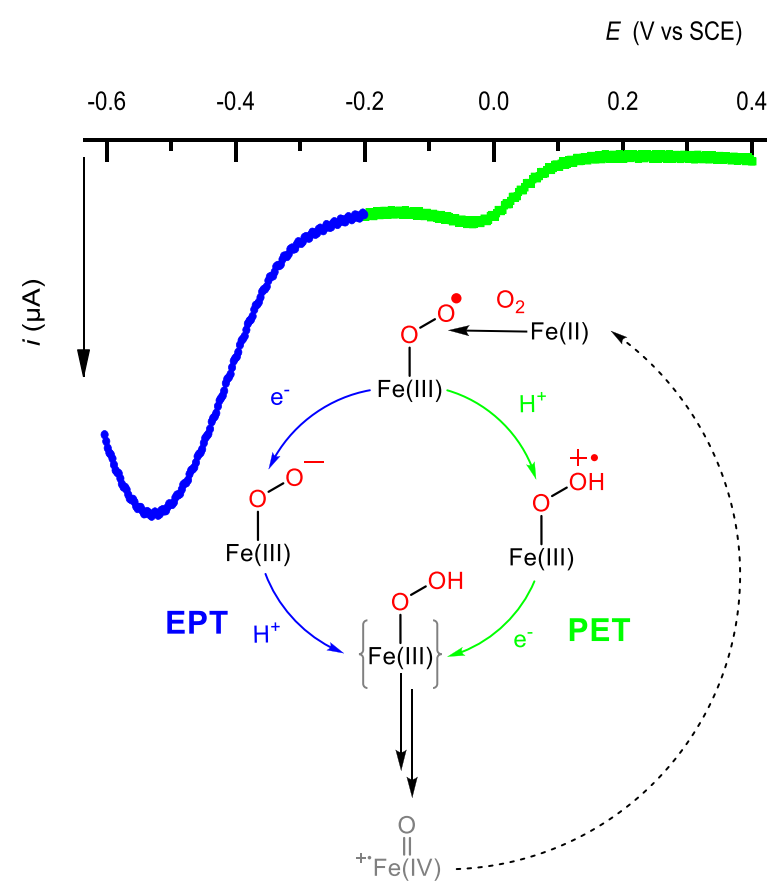

Figure 4. $\mathrm{CV}$ of $1(1 \mathrm{mM})$ in $\mathrm{DMF}+\mathrm{TBAPF}_{6}(0.1 \mathrm{M})$ with $v=0.1 \mathrm{~V}$ $\mathrm{s}^{-1}$ and $\mathrm{T}=293 \mathrm{~K}$, at a glassy-carbon electrode under $\mathrm{O}_{2}$ (air saturated) in the presence of $10 \mathrm{mM} \mathrm{HClO}_{4}$ (after subtraction of the current due to the direct reduction of $\mathrm{O}_{2}$ ) and parallel catalytic pathways occurring at $E_{\text {elec }}=-0.10 \mathrm{~V}$ vs SCE (green) and at $E_{\text {elec }}=$ $-0.60 \mathrm{~V}$ vs SCE (blue), respectively.

Addition of a weaker acid, fluoro-tert-butyl alcohol ( $\mathrm{p} K_{\mathrm{a}}(\mathrm{C}$ $\left.\left(\mathrm{CF}_{3}\right)_{3} \mathrm{OH}\right)$ in DMF $\left.=11.8^{19}\right)$, has no effect on the $\mathrm{Fe}^{\mathrm{III}} / \mathrm{Fe}^{\mathrm{II}}$ wave, while catalytic activity is observed at the level of the peroxo wave (Figure S7), indicating that the superoxo $\mathrm{Fe}^{\mathrm{III}} \mathrm{O}_{2}{ }^{\bullet}$ is less basic than the peroxo $\mathrm{Fe}^{\mathrm{III}} \mathrm{OO}^{-}$. The protonation of the Fe superoxo complex by a strong acid is also supported by the linear variation of the half-wave potential with $\log \left[\mathrm{HClO}_{4}\right]$ (Figure 3). Protonation of a superoxo complex has been previously proposed in water with the iron tetrakis $(N$-methyl4-pyridyl)porphyrin. ${ }^{20}$ Recently Mayer et al. also put forward the formation of the hydrosuperoxo intermediate in organic solvents for the Fe tetrakis phenyl porphyrin. ${ }^{13}$

The present study provides new experimental proof and thermodynamic arguments for the accessibility of the PET pathway, the role of which has been recently taken into consideration for mechanistic analysis catalyzed by the ORR with $\mathrm{Fe}^{13}$ and $\mathrm{Co}^{21}$ porphyrins. Figure 4 summarizes the two different pathways that lead to the formation of $\mathrm{Fe}^{\mathrm{III}} \mathrm{OOH}$ species and to the subsequent $\mathrm{O}-\mathrm{O}$ bond cleavage. The PET process occurs at a low overpotential (green path), while the EPT occurs at a higher overpotential (blue path). A change of the catalytic pathway upon modification of the medium has been evidenced in the case of the ORR catalyzed by ferrocenedecorated $\mathrm{Fe}$ porphyrins. ${ }^{22}$ More recently, thermodynamic aspects of reduction and protonation pathways of a ferric superoxide have been also studied in detail. ${ }^{23}$

It may be noted that the breaking of the $\mathrm{O}-\mathrm{O}$ bond is not the only possible reaction from $\mathrm{Fe}^{\mathrm{III}} \mathrm{OOH} ; \mathrm{Fe}-\mathrm{O}$ bond breaking is also possible, leading to the formation of $\mathrm{H}_{2} \mathrm{O}_{2}$. Nevertheless, it has been shown that the production of $\mathrm{H}_{2} \mathrm{O}_{2}$ is unfavorable in the case of $\mathrm{Fe}$ porphyrins in organic solvents and it may be neglected in mechanistic analyses. 
The observed slow catalytic activity along the PET route offers favorable conditions for detecting intermediate species. To do so, we recorded low-temperature UV-vis spectra upon controlled applied potential $\left(E_{\text {elec }}\right)$ under various acidic conditions.

\section{UV-VIS SPECTROELECTROCHEMISTRY AND DETECTION OF INTERMEDIATES}

Thin-layer UV-vis spectroelectrochemistry can provide useful information about the intermediate species that are formed in the reaction layer surrounding the electrode surface. Upon reduction of an air-saturated solution of 1 at $E_{\text {elec }}=-0.20 \mathrm{~V}$ vs SCE in the presence of 1 equiv of $\mathrm{HClO}_{4}$, the initial $\mathrm{Fe}$ III spectrum (Soret band, $\lambda=414 \mathrm{~nm}$ and $Q$ bands, $\lambda=500,558$, and $610 \mathrm{~nm}$ ) evolves to a new spectrum showing a bathochromic shift of the Soret band a $(\lambda=420 \mathrm{~nm})$ and two new $Q$ bands centered at 530 and $550 \mathrm{~nm}$, respectively (Figure 5A, blue trace). This spectrum is attributed to $\mathrm{Fe}^{\mathrm{II}} \mathrm{OH}^{-}$on the basis of a comparison with the spectrum of an electrochemically prepared $\mathrm{Fe}^{\mathrm{II}} \mathrm{OH}^{-}$in our own experimental configuration in an argon-saturated DMF solution in the presence of $\mathrm{OH}^{-}$(see Figure S8). Hydroxo species of the
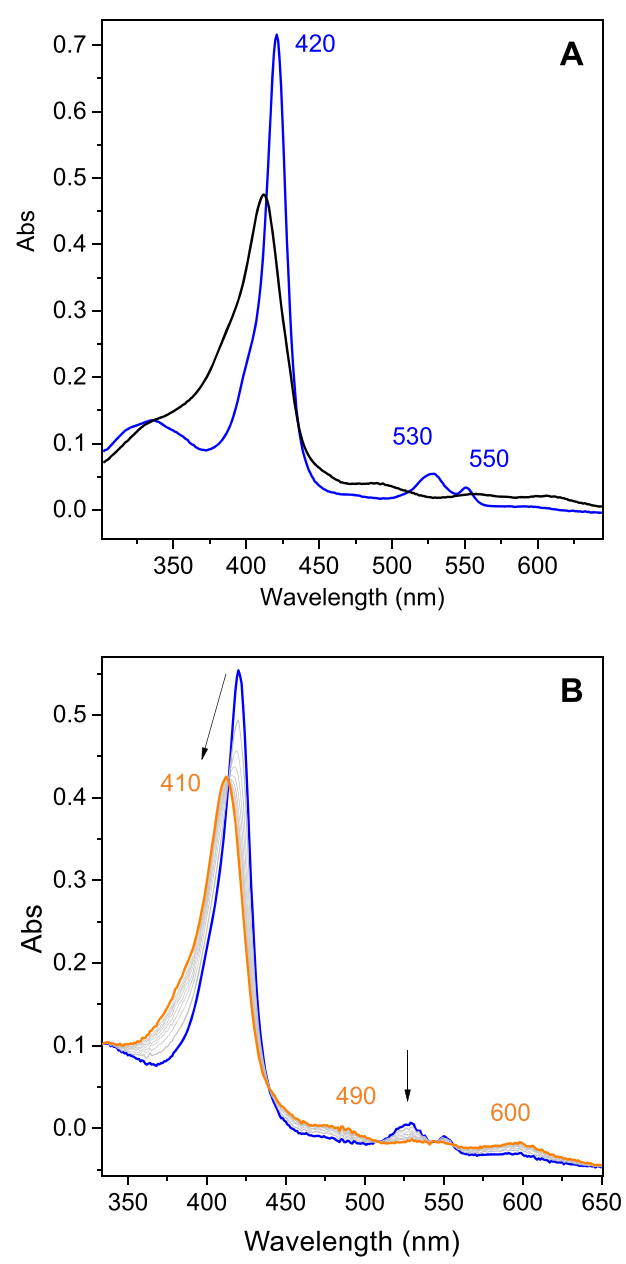

Figure 5. (A) UV-vis spectra of $1(0.05 \mathrm{mM})$ in $\mathrm{DMF}+\mathrm{TBAPF}_{6}$ $(0.2 \mathrm{M})$ at $\mathrm{T}=258 \mathrm{~K}$, under $\mathrm{O}_{2}$ (air saturated) $+\mathrm{HClO}_{4} 0.05 \mathrm{mM}$ at open circuit (black trace) and at $E_{\text {elec }}=-0.20 \mathrm{~V}$ vs SCE after $5 \mathrm{~min}$ (blue trace). (B) Spectral evolution of the same solution upon addition of $\mathrm{HClO}_{4} 0.5 \mathrm{mM}$ at $E_{\text {elec }}=-0.20 \mathrm{~V}$ vs SCE after $5 \mathrm{~min}$ (orange trace). porphyrin under study have been previously generated chemically and characterized by UV-vis spectroscopy in acetonitrile solution. ${ }^{24}$ As partial reduction of $\mathrm{O}_{2}$ to $\mathrm{H}_{2} \mathrm{O}_{2}$ has been reported as a minor pathway in organic media, ${ }^{12}$ we propose that the formation of the $\mathrm{OH}^{-}$ligand results from $\mathrm{O}-$ $\mathrm{O}$ bond cleavage (Scheme 2A) rather than an $\mathrm{H}_{2} \mathrm{O}_{2}$ disproportionation reaction.

Scheme 2. (A) Reactions Taking Place in the Catalytic Cycle Involving the $\mathrm{Fe}^{\mathrm{II}} \mathrm{OH}^{-}$and $\mathrm{Fe}^{\mathrm{IV}} \mathrm{O}$ Species and (B) Disproportionation Reaction of $\mathrm{Fe}^{\mathrm{IV}} \mathrm{O}$

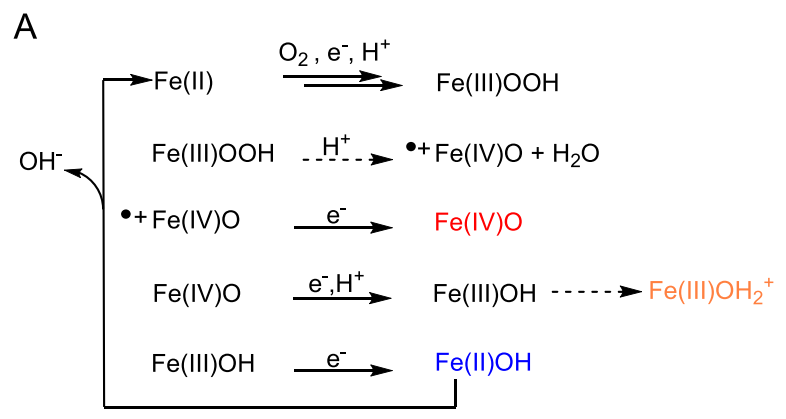

B

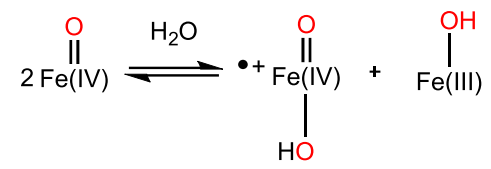

Upon addition of 10 equiv of protons at the same electrode potential $\left(E_{\text {elec }}=-0.20 \mathrm{~V}\right.$ vs SCE), the spectrum evolves to new features at 410 (Soret band) and 490, 555, and $605 \mathrm{~nm}$ (Figure 5B, orange trace) with isosbestic points. This spectrum is close to that of a chemically prepared ferric aquo species (see Figure S9). This new $\mathrm{Fe}^{\mathrm{III}}$ species is less easily reducible than the initial $\mathrm{Fe}^{\mathrm{III}} \mathrm{Cl}$, and its accumulation stops the catalysis. Once protons in the probed optical part of the spectroelectrochemical cell are consumed, the $\mathrm{Fe}^{\mathrm{II}} \mathrm{OH}^{-}$signature appears again (Figure S12).

Upon reduction of an air-saturated solution of $\mathbf{1}$ at more negative potential $(-0.60 \mathrm{~V}$ vs SCE) in the presence of 1 equiv of acid, a characteristic $Q$ band at $547 \mathrm{~nm}$ with a shoulder at $570 \mathrm{~nm}$ appears after $\sim 5 \mathrm{~min}$ (Figure 6, red trace). This spectral signature corresponds to the generation of the highvalent $\mathrm{Fe}^{\mathrm{IV}} \mathrm{O}$ species. Indeed, the spectral signature of this electrochemically produced species matches well to that of a species prepared chemically using an excess of $m$-chloroperbenzoic acid ( $m$-CPBA, see Figure S10) and is also in perfect accordance with data previously published. ${ }^{25-27}$

We propose that the $\mathrm{Fe}^{\mathrm{IV}} \mathrm{O} \pi$ radical cation, resulting from the heterolytic breaking of the $\mathrm{O}-\mathrm{O}$ bond (Scheme 2) in the $\mathrm{Fe}^{\mathrm{III}} \mathrm{OOH}$ complex, can either react with the solvent or be further reduced to $\mathrm{Fe}^{\mathrm{IV}} \mathrm{O}$ (Figure 4) (by the electrode or in solution by the electrogenerated $\left.\mathrm{Fe}^{\mathrm{II}}\right)$. We propose a heterolytic cleavage rather than a homolytic cleavage that could result directly in $\mathrm{Fe}^{\mathrm{IV}} \mathrm{O}$ on the basis of recent studies by Fujii and co-workers, where it is shown that heterolytic cleavage prevails under acidic conditions. ${ }^{28}$

That $\mathrm{Fe}^{\mathrm{IV}} \mathrm{O}$ accumulates under reductive conditions is supported by the disproportionation reaction that takes place between $\mathrm{Fe}^{\mathrm{III}} \mathrm{OH}$ and $\mathrm{Fe}^{\mathrm{IV}} \mathrm{O} \pi$ radical cation (Scheme $2 \mathrm{~B}$ ) and is known to favor $\mathrm{Fe}^{\mathrm{IV}} \mathrm{O}$ formation in organic media. ${ }^{23}$ Under 


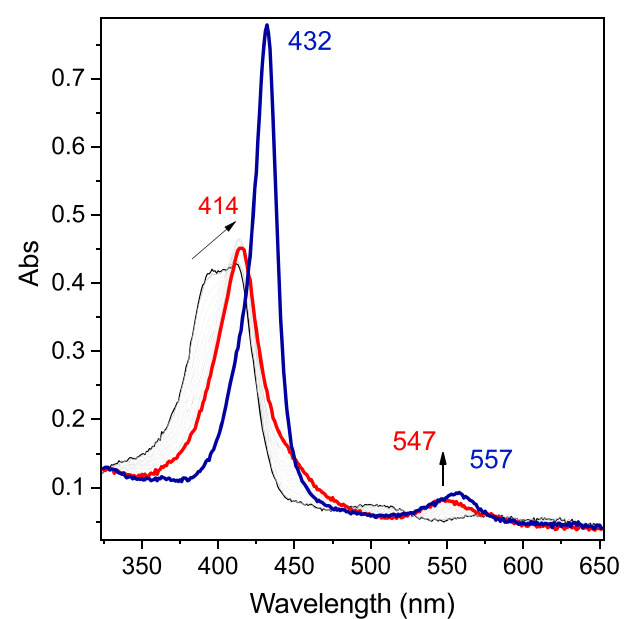

Figure 6. UV-vis spectra of $\mathbf{1}(0.05 \mathrm{mM})$ in DMF $+\mathrm{TBAPF}_{6}(0.2$ $\mathrm{M})$, under $\mathrm{O}_{2}$ (air saturated) $+\mathrm{HClO}_{4}(0.05 \mathrm{mM})$, at $T=258 \mathrm{~K}$ (black trace), with $E_{\text {elec }}=-0.60 \mathrm{~V}$ vs SCE after 5 min electrolysis (red trace), and after 20 min electrolysis (navy blue trace).

our conditions, the electrochemically generated $\mathrm{Fe}^{\mathrm{III}} \mathrm{OH}$ species reacts with the $\mathrm{Fe}^{\mathrm{IV}} \mathrm{O} \pi$ radical cation and leads to $\mathrm{Fe}^{\mathrm{IV}} \mathrm{O}$. The formation of the $\mathrm{Fe}^{\mathrm{IV}} \mathrm{O}$ is further favored by the electron-withdrawing substituents of the porphyrin ring. ${ }^{25}$

The possible involvement of $\mathrm{H}_{2} \mathrm{O}_{2}$ (obtained from direct $\mathrm{O}_{2}$ reduction) in the generation of these high-valent $\mathrm{Fe}$ species was ruled out by control experiments (see Figure S11).

As shown in Figure 6 (blue trace), when a reductive potential $\left(E_{\text {elec }}=-0.60 \mathrm{~V}\right.$ vs SCE$)$ is maintained, after about 20 min the $\mathrm{Fe}^{\mathrm{IV}} \mathrm{O}$ signature fades and the characteristic spectral signature of the $\mathrm{Fe}^{\mathrm{III}} \mathrm{OO}^{-}$species appears (Soret band at 432 $\mathrm{nm}$ and $\mathrm{Q}$ band at $557 \mathrm{~nm}) .{ }^{15}$ Such an evolution is attributed to the consumption of protons in the optical part of the spectroelectrochemical cell before diffusion of protons from the bulk solution compensates it, thus stopping the catalysis. Interestingly, the spectral evolution of $\mathrm{Fe}^{\mathrm{III}} \mathrm{OO}^{-}$at open circuit as a function of time (minutes scale) displays a signature corresponding to $\mathrm{Fe}^{\mathrm{IV}} \mathrm{O}$ species (see Figure S13), as protons of the bulk solution diffuse to the electrode, supporting the proposition that this latter species originates from the $\mathrm{O}-\mathrm{O}$ bond cleavage.

The signature of the $\mathrm{Fe}^{\mathrm{IV}} \mathrm{O}$ species has been previously observed by resonance Raman spectroscopy among signatures of other species under electrocatalytic conditions, in the case of Fe porphyrins immobilized onto gold electrodes. ${ }^{29,30}$ However, to the best of our knowledge, the present observation of accumulated high-valent species under reductive conditions has never been reported. This high-valent species can react with organic molecules such as cyclohexene and toluene. Preparative-scale electrolysis and analysis of the oxidation products are currently being performed and will be the subject of a future publication.

\section{CONCLUSIONS AND PERSPECTIVES}

Using the porphyrin $\mathrm{Fe}^{\mathrm{III}} \mathrm{F}_{20} \mathrm{TPP}$ as a catalyst for the electrochemical reduction of $\mathrm{O}_{2}$ and a combination of $\mathrm{CV}$ and UV-vis spectroelectrochemistry, we have experimentally evidenced two catalytic pathways depending on the applied potential in acidic solutions of $N, N$-dimethylformamide. For the low-overpotential pathway $(-0.20 \mathrm{~V}$ vs SCE) a protonelectron (PET) pathway involving a hydrosuperoxo species has been identified. At large overpotential $(-0.60 \mathrm{~V}$ vs SCE) the electron-proton (EPT) pathway prevails where protonation of $\mathrm{Fe}^{\mathrm{III}}$ peroxo ultimately leading to the formation of high-valent $\mathrm{Fe}^{\mathrm{IV}}$ oxo species dominates. The observation that two different species are accumulated in each catalytic pathway suggests that the kinetics in the $\mathrm{O}-\mathrm{O}$ bond cleavage differ. We thus propose that in the EPT case the more efficient catalysis likely favors the production of a larger amount of high-valent species. The unexpected observation of a high-valent $\mathrm{Fe}$ species under reductive conditions is quite remarkable and reminiscent of the $\mathrm{O}_{2}$ reductive activation process observed in the Cyt P450 cycle. It opens the route to electrochemically triggered activity for oxidation processes using $\mathrm{O}_{2}$ reductive activation. ${ }^{31-33}$

\section{EXPERIMENTAL SECTION}

5.1. Chemicals. All reagents and solvents were obtained commercially (Acros Organics and Aldrich). $\left[\mathrm{Fe}^{\mathrm{III}}\left(\mathrm{F}_{20} \mathrm{TPP}\right) \mathrm{Cl}\right](\mathbf{1})$, tetrabutylammonium hexafluorophosphate $\left(\mathrm{TBAPF}_{6}\right)$ supporting electrolyte, tetrabutylammonium chloride (TBACl), N,N-dimethylformamide (DMF, anhydrous, 99.8\%), silver perchlorate $\left(\mathrm{AgClO}_{4}\right)$, $m$-chloroperbenzoic acid 77\% (m-CPBA), and perchloric acid $70 \%$ $\left(\mathrm{HClO}_{4}\right)$ were used without further purification.

5.2. Cyclic Voltammetry. Electrochemical experiments were run under an argon or $\mathrm{O}_{2}$ atmosphere. A dry $\mathrm{O}_{2}$ atmosphere was obtained by purging the solution with compressed air via a glass tube filled with $\mathrm{CaCl}_{2}$. Cyclic voltammograms were recorded on a Metrohm potentiostat (AUTOLAB Model PGSTAT302N). For cyclic voltammetry, the counter electrode used was a $\mathrm{Pt}$ wire and the working electrode a glassy-carbon disk $(3 \mathrm{~mm}$ diameter) carefully polished before each voltammogram with a $1 \mu \mathrm{m}$ diamond paste, sonicated in an ethanol bath, and then washed with ethanol. The reference electrode used was an SCE (saturated calomel electrode), isolated from the rest of the solution with a fritted bridge. The supporting electrolyte had a concentration of $0.1 \mathrm{M}(293 \mathrm{~K})$ or $0.2 \mathrm{M}$ $(258 \mathrm{~K})$. Low-temperature regulation was ensured by a Julabo circulation cryostat.

5.3. Low-Temperature UV-Visible Spectroelectrochemistry. Thin-cell spectroelectrochemical data were obtained using a combination of three electrodes in a thin cell (optical length $0.2 \mathrm{~cm}$ ) mounted on a UV/vis Varian Cary 60 spectrophotometer, equipped with a transparent Dewar. ${ }^{34}$ It consists of a $0.1 \mathrm{~cm}$ quartz UV-visNIR cell surmounted by a glass compartment. A homemade carbonpaper electrode was used as the working electrode, $\mathrm{Ag} / \mathrm{AgNO}{ }_{3}$ as the reference electrode, and a platinum grid in a frit as the counter electrode. The entire solution was saturated with air $\left(1 \mathrm{mM} \mathrm{O}_{2}\right)$, and the cell was cooled to $258 \mathrm{~K}$ by a Julabo circulation cryostat.

\section{ASSOCIATED CONTENT}

$\mathrm{CV}$ analysis and simulation, including the $\mathrm{CVs}$ of an airsaturated DMF solution with increasing amounts of protons in the presence and absence of $\left[\mathrm{Fe}^{\mathrm{III}}\left(\mathrm{F}_{20} \mathrm{TPP}\right)\right.$ $\mathrm{Cl}], \mathrm{CVs}$ of $\left[\mathrm{Fe}^{\mathrm{III}}\left(\mathrm{F}_{20} \mathrm{TPP}\right)\right]^{+}(\mathbf{1}-\mathrm{DMF})$ and $\left[\mathrm{Fe}^{\mathrm{III}}\left(\mathrm{F}_{20} \mathrm{TPP}\right) \mathrm{Cl}\right]$ (1-Cl) in DMF under argon, and $\left[\mathrm{Fe}^{\mathrm{III}}\left(\mathrm{F}_{20} \mathrm{TPP}\right) \mathrm{Cl}\right](\mathbf{1})$ in DMF under argon in the presence of $\mathrm{HClO}_{4}$, the variation of the $i_{\mathrm{p}} / i^{0}$ ratio of the $\mathrm{Fe}{ }^{\mathrm{III}} / \mathrm{Fe}^{\mathrm{II}}$ wave potential of $\mathbf{1 - C l}$ with acid concentration under catalytic conditions, the effects of $\mathrm{C}\left(\mathrm{CF}_{3}\right)_{3} \mathrm{OH}$, and CVs of chemically prepared $\mathrm{Fe}^{\mathrm{III}}$ and $\mathrm{Fe}^{\mathrm{IV}} \mathrm{O}$ species of $\mathrm{Fe}\left(\mathrm{F}_{20} \mathrm{TPP}\right), \mathrm{UV}$-vis absorption spectra of chemically prepared $\mathrm{Fe}^{\mathrm{II}} \mathrm{Fe}^{\mathrm{III}}$ and $\mathrm{Fe}^{\mathrm{IV}} \mathrm{O}$ species of the $\mathrm{Fe}\left(\mathrm{F}_{20} \mathrm{TPP}\right)$, Addition of $\mathrm{H}_{2} \mathrm{O}_{2}$ to an acidic [ $\left.\mathrm{Fe}^{\mathrm{III}}\left(\mathrm{F}_{20} \mathrm{TPP}\right) \mathrm{Cl}\right]$ 
solution, and evolution of $\mathrm{Fe}^{\mathrm{III}} \mathrm{OH}_{2}{ }^{+}$and $\mathrm{Fe}^{\mathrm{III}} \mathrm{OO}^{-}$ species of $\mathrm{Fe}\left(\mathrm{F}_{20} \mathrm{TPP}\right)$ (PDF)

\section{AUTHOR INFORMATION}

\section{Corresponding Author}

Elodie Anxolabéhère-Mallart - Université de Paris,

Laboratoire d'Electrochimie Moleculaire, CNRS, F-75013 Paris,

France; (1) orcid.org/0000-0002-8708-802X;

Email: elodie.anxolabehere u-paris.fr

\section{Authors}

Nikolaos Kostopoulos - Université de Paris, Laboratoire d'Electrochimie Moleculaire, CNRS, F-75013 Paris, France

Célia Achaibou - Université de Paris, Laboratoire d'Electrochimie Moleculaire, CNRS, F-75013 Paris, France

Jean-Marc Noël - Universite de Paris, ITODYS, CNRS, F75013 Paris, France

Frédéric Kanoufi - Université de Paris, ITODYS, CNRS, F75013 Paris, France; ○ orcid.org/0000-0002-9784-2380

Marc Robert - Université de Paris, Laboratoire d'Electrochimie Moleculaire, CNRS, F-75013 Paris, France; Institut Universitaire de France (IUF), F-75005 Paris, France; (1) orcid.org/0000-0001-7042-4106

Claire Fave - Universite de Paris, Laboratoire d'Electrochimie Moleculaire, CNRS, F-75013 Paris, France; 이이.org/ 0000-0001-8146-8702

Complete contact information is available at:

https://pubs.acs.org/10.1021/acs.inorgchem.0c01379

\section{Notes}

The authors declare no competing financial interest.

\section{ACKNOWLEDGMENTS}

We thank the LabEx MiChem part of French state funds managed by the ANR within the Investissements d'Avenir programme under reference ANR-11-IDEX-0004-02 (E.A.-M., C.A., C.F., F.K., and J.-M.N.). N.K. acknowledges funding from the French government for his Ph.D. Partial financial support to M.R. from the Institut Universitaire de France (IUF) is also gratefully acknowledged. E.A.-M. thanks Pr. Frédéric Banse (ICMMO, Université Paris Saclay) for fruitful discussions.

\section{ABBREVIATIONS}

PET proton electron transfer EPT electron proton transfer DMF $N, N$-dimethylformamide ORR oxygen reduction reaction CytP450 cytochrome P450 oxidase SCE standard calomel electrode $\mathrm{CV}$ cyclic voltammetry or cyclic voltammograms

\section{REFERENCES}

(1) Cavani, F. J. H.; Teles, J. H. Sustainability in catalytic oxidation: an alternative approach or a structural evolution? ChemSusChem 2009, 2, 508-534.

(2) Sheldon, R. A.; Arends, I. W. C. E.; Hanefeld, U. In Green Chemistry and Catalysis; Wiley-VCH: 2007; pp 133-221.

(3) Meunier, B.; De Visser, S. P.; Shaik, S. Mechanism of Oxidation Reactions Catalyzed by Cytochrome P450 Enzymes. Chem. Rev. 2004, 104, 3947-3980.

(4) Denisov, I. G.; Makris, T. M.; Sligar, S. G.; Schlichting, I. Structure and Chemistry of Cytochrome P450. Chem. Rev. 2005, 105, $2253-2278$.
(5) Ortiz de Montellano, P. R. Hydrocarbon Hydroxylation by Cytochrome P450 Enzymes. Chem. Rev. 2010, 110, 932-948.

(6) Huang, X.; Groves, J. T. Oxygen Activation and Radical Transformations in Heme Proteins and Metalloporphyrins. Chem. Rev. 2018, 118, 2491-2553.

(7) Kaila, V. R. I.; Verkhovsky, M. I.; Wikström, M. Proton-Coupled Electron Transfer in Cytochrome Oxidase. Chem. Rev. 2010, 110, $7062-7081$.

(8) Yoshikawa, S.; Shimada, A. Reaction mechanism of cytochrome c oxidase. Chem. Rev. 2015, 115, 1936-1989.

(9) Groves, J. T.; Han, Y.-Z. Models and mechanisms of Cytochrome P450 Action; Ortiz de Montellano, P. R., Ed.; Springer: Boston, MA, 1995.

(10) Tani, F.; Matsu-Ura, M.; Nakayama, S.; Naruta, Y. Synthetic models for the active site of cytochrome P450. Coord. Chem. Rev. 2002, 226, 219-226.

(11) Collman, J. P.; Boulatov, R.; Sunderland, C.; Fu, L. Functional Analogues of Cytochrome $\mathrm{c}$ Oxidase, Myoglobin, and Hemoglobin. Chem. Rev. 2004, 104, 561-588.

(12) Pegis, M. L.; McKeown, B. A.; Kumar, N.; Lang, K.; Wasylenko, D. J.; Zhang, X. P.; Raugei, S.; Mayer, J. M. Homogenous Electrocatalytic Oxygen Reduction Rates Correlate with Reaction Overpotential in Acidic Organic Solutions. ACS Cent. Sci. 2016, 2, 850-856.

(13) Pegis, M. L.; Martin, D. J.; Wise, C. F.; Brezny, A. C.; Johnson, S. I.; Johnson, L. E.; Kumar, N.; Raugei, S.; Mayer, J. M. Mechanism of Catalytic $\mathrm{O}_{2}$ Reduction by Iron Tetraphenylporphyrin. J. Am. Chem. Soc. 2019, 141, 8315-8326.

(14) Anxolabéhère-Mallart, E.; Bonin, J.; Fave, C.; Robert, M. Smallmolecule activation with iron porphyrins using electrons, photons and protons: some recent advances and future strategies. Dalton Trans. 2019, 48, 5869-5878.

(15) Oliveira, R.; Zouari, W.; Herrero, C.; Banse, F.; Schöllhorn, B.; Fave, C.; Anxolabéhère-Mallart, E. Characterization and Subsequent Reactivity of an Fe-Peroxo Porphyrin Generated by Electrochemical Reductive Activation of $\mathrm{O}_{2}$. Inorg. Chem. 2016, 55, 12204-12210. In this study, the spectrum with $\lambda_{\max }=420,530,550 \mathrm{~nm}$ has been mistakenly attributed to $\mathrm{Fe}^{\mathrm{III}} \mathrm{OO}^{\bullet}$; according to our current knowledge this spectrum corresponds to the $\mathrm{Fe}^{\mathrm{II}} \mathrm{OH}$ complex.

(16) Gueutin, C.; Lexa, D.; Savéant, J. M.; Wang, D. L. $\sigma$-Alkyl Iron Porphyrins from Sterically Encumbered Alkyl Halides and lron (“0")Porphyrins. Organometallics 1989, 8, 1607-1613.

(17) Savéant, J.-M. In Elements of Molecular and Biomolecular Electrochemistry; Wiley-Interscience: New York, 2006.

(18) Wasylenko, D. J.; Rodríguez, C.; Pegis, M. L.; Mayer, J. M. Direct comparison of electrochemical and spectrochemical kinetics for catalytic oxygen reduction. J. Am. Chem. Soc. 2014, 136, 1254412547.

(19) Izutsu, K., Acid-Base Dissociation Constants in Dipolar Aprotic Solvents, Blackwell Scientific Publications, Brookline Village, 1990, Vol. 35, p 166.

(20) Costentin, C.; Dridi, H.; Savéant, J. M. Molecular Catalysis of $\mathrm{O}_{2}$ Reduction by Iron Porphyrins in Water: Heterogeneous versus Homogeneous Pathways. J. Am. Chem. Soc. 2015, 137, 13535-13544.

(21) Wang, Y. H.; Schneider, P. E.; Goldsmith, Z. K.; Mondal, B.; Hammes-Schiffer, S.; Stahl, S. S. Bronsted Acid Scaling Relationships Enable Control Over Product Selectivity from $\mathrm{O}_{2}$ Reduction with a Mononuclear Cobalt Porphyrin Catalyst. ACS Cent. Sci. 2019, 5, 1024-1034.

(22) Mittra, K.; Chatterjee, S.; Samanta, S.; Dey, A. Selective 4e-/4H $+\mathrm{O}_{2}$ reduction by an iron(tetraferrocenyl)porphyrin complex: from proton transfer followed by electron transfer in organic solvent to proton coupled electron transfer in aqueous medium. Inorg. Chem. 2013, 52 (24), 14317-25.

(23) Kim, H.; Rogler, P. J.; Sharma, S. K.; Schaefer, A. W.; Solomon, E. I.; Karlin, K. D. Heme-Fe(III) Superoxide, Peroxide and Hydroperoxide Thermodynamic Relationships: $\mathrm{Fe}^{\mathrm{III}}-\mathrm{O}_{2}{ }^{--}$Complex H-Atom Abstraction Reactivity. J. Am. Chem. Soc. 2020, 142 (6), 3104-3116. 
(24) Franke, A.; Fertinger, C.; van Eldik, R. Axial Ligand and SpinState Influence on the Formation and Reactivity of HydroperoxoIron(III) Porphyrin Complexes. Chem. - Eur. J. 2012, 18, 6935-6949.

(25) Pan, Z.; Newcomb, M. Kinetics and Mechanism of Oxidation Reactions of Porphyrin-Iron(IV)-Oxo Intermediates. Inorg. Chem. 2007, 46, 6767-6774.

(26) Cong, Z.; Yanagisawa, S.; Kurahashi, T.; Ogura, T.; Nakashima, S.; Fujii, H. Synthesis, characterization, and reactivity of hypochloritoiron(III) porphyrin complexes. J. Am. Chem. Soc. 2012, 134, 20617-20620.

(27) Cong, Z.; Kurahashi, T.; Fujii, H. Oxidation of chloride and subsequent chlorination of organic compounds by oxoiron(IV) porphyrin pi-cation radicals. Angew. Chem., Int. Ed. 2011, 50, 99359939.

(28) Yokota, S.; Fujii, H. Critical Factors in Determining the Heterolytic versus Homolytic Bond Cleavage of Terminal Oxidants by Iron(III) Porphyrin Complexes. J. Am. Chem. Soc. 2018, 140 (15), $5127-5137$.

(29) Sengupta, K.; Chatterjee, S.; Samanta, S.; Dey, A. Direct observation of intermediates formed during steady-state electrocatalytic $\mathrm{O}_{2}$ reduction by iron porphyrins. Proc. Natl. Acad. Sci. U. S. A. 2013, 110, 8431-8436.

(30) Sengupta, K.; Chatterjee, S.; Dey, A. In Situ Mechanistic Investigation of $\mathrm{O}_{2}$ Reduction by Iron Porphyrin Electrocatalysts Using Surface-Enhanced Resonance Raman Spectroscopy Coupled to Rotating Disk Electrode (SERRS-RDE) Setup. ACS Catal. 2016, 6 (10), 6838-6852.

(31) Minteer, S.; Baran, P. Electrifying Synthesis: Recent Advances in the Methods, Materials, and Techniques for Organic Electrosynthesis. Acc. Chem. Res. 2020, 53 (3), 545-546.

(32) Anxolabéhère-Mallart, E.; Banse, F. Bioinspired molecular catalysts for homogenous electrochemical activation of dioxygen. Current Opinion in Electrochemistry 2019, 15, 118-124.

(33) Sengupta, K.; Chatterjee, S.; Samanta, S.; Bandyopadhyay, S.; Dey, A. Resonance Raman and electrocatalytic behavior of thiolate and imidazole bound iron porphyrin complexes on self assembled monolayers: functional modeling of cytochrome P450. Inorg. Chem. 2013, 52 (4), 2000-14.

(34) Gueutin, C.; Lexa, D. Low temperature spectroelectrochemistry for the characterization of highly reduced $\sigma$-alkyl iron halogenated porphyrins. Electroanalysis 1996, 8, 1029-1033. 